\title{
PENGARUH METODE LATIHAN SIRKUIT, METODE KONVENSIONAL TERHADAP KETERAMPILAN DASAR BOLA BASKET
}

\author{
Feby Elra Perdima
}

\author{
Correspondence: Universitas Dehasen Bengkulu, Bengkulu, Indonesia \\ E-mail: Perdima.elra@gmail.com
}

\begin{abstract}
Based on the researchers abservation on the field, the student's of SMA Negeri 1 Lebong Utara shill have lack of basic skill of basketball. This research aimed to explain the different effect between sirkuit exercise method and convensional method toward the increasing of student basic skill of basketball of SMA Negeri 1 Lebong Utara. This research is quasi experimental research the population of this research was 32 student. The sampling techique that used in this research was jenuh smpling techique. So that 32 student's was choosen. the test used in this research were driible zig-zag, passing, under basket. Which aimed to know the student's basic skill of basketball at SMA Negeri 1 Lebong Utara. Analysis technique that was used in this recearch was $t$-test. The result of data analysis showed that (1) sirkuit exercise method can increase the student basic skill of basketball at SMA Negeri 1 SMA Negeri 1 Lebong Utara $\left(t_{\text {observed }} 16,77>t_{\text {table }}=0,051,75\right)(2)$ convensional method can increase the student's basic skill of basketball at SMA Negeri 1 Lebong Utara ( $\left.t_{\text {observed }} 9,25>t_{\text {table }}=0,051,75\right)$ (3) there is significant differences betwenn sirkuit exercise method with convensional method toward student's basic skill of basketball at SMA Negeri 1 Lebong Utara ( $\left.t_{\text {observed }} 3,50>t_{\text {tablea }}=0,051,75\right)$.
\end{abstract}

\section{Keywords: Sirkuit Exercise, Convensional of Basketball}

\section{Pendahuluan}

Bolabasket adalah suatu permainan yang dimainkan secara tim yang setiap tim terdiri dari 5 orang, sehingga diperlukan suatu kerjasama tim dan keterampilan dari masing-masing individu. Dalam permainan bolabasket, seorang pemain dituntut selalu bergerak sambil memperagakan teknik-teknik dasar bolabasket, berusaha memasukkan bola ke ring lawan sebanyak-banyaknya tanpa mendapat gangguan dari lawan serta berusaha mencegah lawan untuk memasukkan bola ke dalam ring. Hal ini artinya, untuk dapat bermain bolabasket dengan baik dibutuhkan penguasaan teknik yang baik dan kualitas fisik yang memadai. seorang pemain bolabasket juga harus menguasai berbagai teknik dasar dalam bermain bolabasket seperti menembak, menggiring, mengumpan, pivot dan lain-lain.

SMA Negeri 1 adalah salah satu sekolah yang berada di Kabupaten Lebong, dimana sekolah SMA Negeri 1 ini turut serta melakukan pembinaan dalam olahraga terutama cabang olahraga bolabasket. Pembinaan olahraga di SMA Negeri 1 Lebong Utara dengan mengadakan ekstrakurikuler. SMA Negeri 1 Lebong Utara ini melaksanakan pembinaan cabang olahraga bolabasket 3 kali dalam satu minggu. Seharusnya SMA Negeri Lebong Utara ini melahirkan para pemain yang terampil dalam bermain bolabasket, serta memiliki keterampilan 
dribbling, passing, dan shooting sangat baik, dikarenakan SMA Negeri 1 Lebong Utara ini telah melaksanakan latihan bolabasket secara kontinyu.

Pada saat melakukan pengamatan dalam pelaksanaan kegiatan ekstrakurikuler bolabasket di SMA Negeri 1 maka terlihatlah masih kurangnya keterampilan dasar bolabasket seperti dribbling, passing dan shooting yang mereka miliki masih kurang baik. Hal ini terlihat saat melakukan dribbling bola yang mereka kuasai sangat mudah di rampas oleh lawan karena pada saat melakukan dribbling mereka masih kaku, masih tergesa-tergesa sehingga melakukan dribbling kurang lancar. Selain itu juga kurangnya kecepatan dan tepat dalam melakukan passing, itu terlihat saat ketika pemain mengoper bola kepada temannya sering bola yang diberikan itu tidak tepat, dan mudah dirampas oleh lawan. Dan terakhir pada saat melakukan shooting bola jarang masuk ke dalam ring padahal pemain SMA Negeri 1 tanpa kawalan dan dalam posisi dekat ke ring bolabasket. Oleh karena keterampilan dasar bolabasket siswa SMA Negeri 1 yang mengikuti ekstrakurikuler masih rendah, sehingga sering menerima kekalahan di tingkat Kabupaten maupun Provinsi. Kenyataan ini tentu akan mempengaruhi keterampilan dasar bolabasket siswa SMA Negeri 1 Lebong Utara yang mengikuti ekstrakurikuler.

Maka dari itu diperlukan usaha yang segera guna mencari pemecahannya. Pembinaan dan perkembangan olahraga bolabasket di SMA Negeri 1 Lebong Utara perlu di upayakan dengan optimal, Hal ini diharapkan dapat memberikan kontribusi dalam membina, serta meningkatkan keterampilan bolabasket dan bahkan melahirkan pemain bolabasket yang dapat meraih prestasi, baik kejuaraan daerah maupun nasional. Salah satu upaya yang paling strategis untuk meningkatkan keterampilan bolabasket, peneliti ingin menerapkan suatu metode latihan dengan menggunakan pos-pos, dimana setiap pos itu memiliki berberapa bentuk latihan yang berbeda-beda. Karena dengan menggunakan bentuk latihan yang berbeda-beda di setiap posnya, kita dapat meningkatkan keterampilan bolabasket secara serempak dalam waktu relatif singkat serta menjadikan latihan yang menyenangkan karena memilki variasi bentuk latihan. Metode latihan yang dimaksud adalah metode latihan sirkuit.

Hal ini, mengenai keterampilan bolabasket diperlukan metode latihan yang lebih tepat. Penggunaan metode dan bentuk latihan yang salah dapat menimbulkan hasil yang tidak tepat. Berdasarkan uraian di atas, maka penulis tertarik untuk melakukan penelitian tentang sejauh mana pengaruh metode latihan sirkuit dan metode konvensional dalam meningkatkan keterampilan dasar bolabasket siswa SMA Negeri 1 Lebong Utara yang mengikuti kegiatan ekstrakurikuler bolabasket. 


\section{Pustaka}

Kiram (2001: 11) mengatakan bahwa keterampilan adalah tindakan yang memerlukan aktivitas gerak yang harus dipelajari agar mendapatkan bentuk gerakan yang benar. Berdasarkan uraian di atas, maka dapat disimpulkan bahwa keterampilan berkaitan dengan bentuk-bentuk keterampilan gerak dasar yang ditampilkan dalam bentuk garakan yang benar, tepat, efektif dan efesien.

Arifin (2004: 16) menjelaskan bahwa "bolabasket merupakan olahraga yang mengandung unsur-unsur gerakan yang komplek dan beragam, artinya gerakan-gerakan yang dibutuhkan dalam bermain bola basket merupakan gabungan dari unsur-unsur gerakan yang saling menunjang”.

Menurut Khoreon (2017: 1) bola basket adalah sebuah cabang olahraga yang dimana bola menjadi media utama dalam berjlannya sebuah permainan olahraga ini dilakukan oleh dua tim dan setiap tim terdiri dari lima pemain. Cara bermain permainan ini adalah dengan memasukan bola ke dalam sebuah keranjang dan menumpulkan point sebanyak mungkin agar keluar menjadi pemenang. Menurut Elra (2017: 2) pengertian permainan bolabasket adalah “ suatu permainan yang dimainkan oleh 5 orang pemain melawan 5 orang pemain yang bertujuan memasukan bola sebanyak-banyaknya ke dalam ring lawan sehingga mencapai suatu kemenangan.

Teknik dasar bolabasket diantaranya seperti (1) Dribbling, Elra (2017:50) mengemukakan bahwa "dribbling adalah Dribbling adalah salah satu teknik dasar dalam bolabasket dengan cara menguasai bola sambil bergerak untuk mengamankan bola dari rampasan oleh lawan. Bola di pantulkan ke lantai, sesuai peraturan yang disyahkan. Pada awalnya bola harus lepas dari tangan sebelum kaki anda di angkat ke lantai, sementara mengiring bola tidak boleh menyentuh bola dengan dua tangan. (2) Passing Menurut Dinata (2013:30) passing adalah "Salah satu teknik dasar bola basket yang bertujuan untuk mengoper bola ke teman satu tim". (3) Shooting, Menurut Darmawan (2001: 76) shooting adalah "teknik dasar yang berperan sangat penting dalam memenangkan pertandingan, dikarena ide permainan bola basket dalam memasukan bola ke ring lawan sebanyak mungkin ".

Irawadi (2010: 11) metode latihan sirkuit adalah "suatu bentuk latihan yang menggunakan pos-pos, dimana pada setiap pos dilakukan suatu bentuk kegiatan latihan yang berbeda-beda". Dari penjelasan teori di atas maka dapat dijelaskan bahwa latihan sirkuit ini merupakan suatu rangkaian, dimana setelah selesai pada satu pos, maka pindah dari pos ke pos dilakukan secara berurut, dan diselingi oleh waktu istirahat. Latihan biasanya dilakukan dengan beberapa kali pengulangan (set), dari set ke set berikutnya juga diberikan waktu istirahat. Waktu istirahat antar set lebih lama daripada waktu istirahat antar pos. Menurut Rusli Lutan (2000: 78) latihan sirkuit adalah salah satu cara yang dapat memperbaiki secara serempak tingkat kebugaran keseluruhan dari tubuh seorang olahragawan yang meliputi komponen biomotor dasar. Sukadiyanto (2005: 28) latihan sirkuit adalah ukuran keberhasilan dalam menyelesaikan beberapa rangkaian butir latihan yang berbeda-beda. Artinya dalam satu sirkuit terdiri atas beberapa macam latihan yang semuanya harus diselesaikan dalam satu rangkaian.

PJKR_

http://jurnal.unimed.ac.id/2012/index.php/jpehr/index 
Metode konvensional mempunyai beberapa pengertian menurut Zalpendi (2010: 91), metode konvensional adalah "Proses pembelajaran atau latihan yang dilakukan sebagaimana umumnya pelatih mengajarkan materi kepada siswa". Pelatih mentransfer ilmu pengetahuan kepada siswa.

Berdasarkan penjelasan di atas maka metode konvensional adalah metode latihan yang didominasi oleh metode ceramah, dimana latihan ini berorientasi pada pelatih dan hampir seluruh kegiatan latihan dikendalikan oleh pelatih. Kegiatan pelatih meliputi apersepsi, motivasi, memperkenalkan materi latihan, menyampaikan materi latihan di depan siswa secara langsung, pemberian beberapa buah contoh fase gerakan teknik dasar dan latihan kepada siswa, kemudian memberikan kesimpulan atau ringkasan materi latihan. Dalam metode konvensional, mengajar ditafsirkan sebagai kegiatan memasukkan isi atau bahan materi dari buku kepada siswa sehingga mereka dapat mengeluarkan kembali segala informasi waktu tes diberikan

\section{Metode}

Jenis Penelitian ini menggunakan metode penelitian eksperimen semu (Quasi Exsperimen). Menurut Sugiyono (2007: 73), "penelitian eksperimen semu adalah penelitian yang mendekati percobaan sesungguhnya dimana tidak mungkin mengadakan kontrol memanipulasikan semua variabel yang relevan" dilihat dari lokasi penelitian maka penelitian ini termasuk jenis penelitian eksperimen lapangan. Tujuannya adalah untuk menemukan ada tidaknya pengaruh perlakuan antara sebab dengan akibat antara variabel-variabel yang dikontrol (independent variables and dependent variables), Suharno, dkk, (2004: 14).

Penelitian ini dimaksudkan untuk mengetahui pengaruh latihan sirkuit dan metode konvensional terhadap keterampilan dasar bolabasket siswa SMA Negeri 1 Lebong Utara. Penelitian ini memiliki dua variabel bebas terhadap satu variabel terikat. Veriabel bebas (X) yang dimaksud dalam penelitian ini yaitu metode latihan sirkuit $\left(\mathrm{X}_{1}\right)$ dan metode konvensional. Sedangkan variabel terikatnya adalah keterampilan dasar bolabasket.

\section{Pembahasan}

1. Terdapat Pengaruh Metode Latihan Sirkuit yang Signifikan Terhadap Peningkatan Keterampilan Dasar Bolabasket Siswa SMA Negeri 1 Lebong Utara.

Berdasarkan Data hasil pengujian hipotesis 1 metode latihan sirkuit terlihat bahwa $t_{\text {hitung }}(16,77)>t_{\text {tabel }}(1,75)$. Hal ini berarti bahwa hipotesis penelitian dapat diterima. Dengan demikian dapat diartikan bahwa metode latihan sirkuit memberikan pengaruh yang signifikan terhadap keterampilan dasar bolabasket siswa SMA Negeri 1 Lebong Utara. hal ini tergambar dari selisih antara pretest $(53,22)$ dan post-test $(61,43)$ dengan perhitungan selisih menjadi $(8,21)$ artinya disini bahwa metode latihan sirkuit memberikan pengaruh yang signifikan terhadap keterampilan dasar bolabasket siswa SMA Negeri 1 Lebong Utara. 
2. Terdapatnya Pengaruh Metode Konvensional yang signifikan Terhadap

Peningkatan Keterampilan Dasar Bolabasket SMA Negeri 1 Lebong Utara.

Berdasarkan data hasil pengujian hipotesis 2 metode konvensional terlihat bahwa $t_{\text {hitung }}(9,25)>t_{\text {tabel }}(1,75)$. Hal ini berarti bahwa hipotesis penelitian dapat diterima. Dengan demikian dapat diartikan bahwa bahwa metode konvensional memberikan pengaruh yang signifikan terhadap keterampilan dasar bolabasket siswa SMA Negeri 1 Lebong Utara. hal ini tergambar dari selisih antara pre-test $(53,13)$ dan post-test $(58,68)$ dengan perhitungan selisih menjadi $(5,55)$ artinya disini bahwa metode latihan sirkuit memberikan pengaruh yang signifikan terhadap keterampilan dasar bolabasket siswa SMA Negeri 1 Lebong Utara.

3. Terdapat Pengaruh Metode Latihan Sirkuit Lebih Besar dibandingkan dengan Metode Konvensional Terhadap Keterampilan Dasar Bolabasket Siswa SMA Negeri 1 Lebong Utara.

Berdasarkan data hasil pengujian hipotesis 3 terlihat bahwa thitung $(3,50)>$ $t_{\text {tabel }}(1,75)$. Hal ini berarti bahwa hipotesis penelitian dapat diterima. Dengan demikian terdapat perbedaan pengaruh yang signifikan antara metode latihan sirkuit dengan metode konvensional $t_{\text {hitung }}>t_{\text {tabel }}(3,50>1,75)$.

Hal ini tergambar dari selisih masing-masing yaitu dimana selisih antara pre-tes dengan post-tes metode latihan sirkuit $(8,21)$ dan metode konvensional $(5,55)$ artinya disini bahwa terdapat pengaruh metode latihan sirkuit lebih besar dibandingkan dengan metode konvensional terhadap peningkatan keterampilan dasar bolabasket siswa SMA Negeri 1 Lebong Utara.

\section{Simpulan}

Berdasarkan analisis data dan pembahasan yang telah dipaparkan terdahulu, maka dapat dikemukakan beberapa kesimpulan Sebagai berikut:

1. Metode Latihan Sirkuit memberikan pengaruh yang signifikan terhadap keterampilan dasar bolabasket siswa SMA Negeri 1 Lebong Utara, hasil yang diperoleh thitung $16,77>\mathrm{t}_{\text {tabel }} \alpha=0,051,75$ yang artinya hipotesis diterima dengan rata-rata pada pre-test 53,22 meningkat menjadi 61,43 pada posttest.

2. Metode Konvensional memberikan pengaruh yang signifikan terhadap keterampilan dasar bolabasket siswa SMA Negeri 1 Lebong Utara, hasil yang diperoleh $t_{\text {hitung }} 9,25>t_{\text {tabel }}=0,051,75$ yang artinya hipotesis diterima dengan rata-rata pada pre-test 53,13 meningkat menjadi 58,68 pada posttest.

3. Metode Latihan Sirkuit memberikan pengaruh lebih besar dibandingkan dengan Metode konvensional untuk meningkatkan keterampilan dasar bolabasket siswa SMA Negeri 1 Lebong Utara, dimana hasil yang diperoleh thitung $3,50<t_{\text {tabel }}=0,051,75$.

\section{Rujukan}

Arifin, Mochamad, 2004. Metode Pelatihan Bola Basket dasar. Surabaya. Diktat. 
Darmawan, Gede Eka Budi, 2001. Cabang Olahraga Bola Basket. Jakarta: Graha Ilmu

Dinata, Marta, 2013. Bola Basket Konsep Dan Teknik Bermain Bola Basket. Jakarta: Cerdas Jaya

Elra.Perdima, 2017. Bola Basket Dasar. Bengkulu: Universitas dehasen Bengkulu Press

Irawadi, Hendri, 2010. Kondisi Fisik dan Pengukurannya. Padang: FIK Universitas Negeri Padang.

Khoeron, Nidhom. 2017. Basket Pintar. Jakarta Timur: Anugrah

Rusli Lutan, 2000. Dasar Kepelatihan: Departemen Pendidikan dan Kebudayaan. Direktorat Jendral Pendidikan Dasar dan Menengah

Sugiyono, 2007. Metode penelitian pendidikan (pendekatan kuantitatif, kualitatif, dan $R \& D)$. Bandung: Alfabeta.

Sukadiyanto. 2005. Pengantar Teori dan Metodelogi Melatih Fisik. Yogyakarta. Fakultas Ilmu Keolahragaan. Universitas Negeri Yogyakarta

Suharno, 2004. Metodologi Pelatihan. Jakarta: Komite Olahraga Nasional Indonesia Pusat.

Yanuar Kiram, 2001. Metode Pembelajaran Keterampilan Motorik Dasar Bagi Anak-Anak Sekolah Dasar. Universitas Negeri Padang

Zalfendi, 2010. Analisis Kurikulum Dalam Pembelajaran Penjasorkes. Padang: Sukabina. 